

\section{DASAR-DASAR MANAJEMEN Teori, Fungsi dan Konsep}

Ade Onny Siagian, M.M., M.H., M.A.P., M.I.Kom.

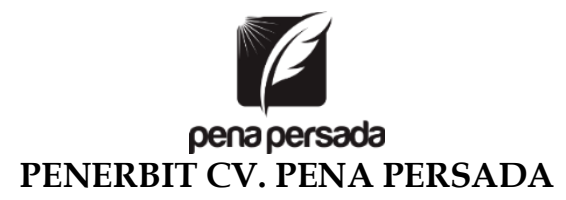




\section{DASAR-DASAR MANAJEMEN \\ Teori, Fungsi dan Konsep}

Penulis:

Ade Onny Siagian, M.M., M.H., M.A.P., M.I.Kom.

ISBN : 978-623-315-132-0

Design Cover :

Retnani Nur Briliant

Layout :

Rusfik Yulli Anur Wati

\section{Penerbit CV. Pena Persada}

Redaksi :

Jl. Gerilya No. 292 Purwokerto Selatan, Kab. Banyumas

Jawa Tengah

Email : penerbit.penapersada@gmail.com

Website : penapersada.com Phone : (0281) 7771388

Anggota IKAPI

All right reserved

Cetakan pertama : 2020

Hak Cipta dilindungi oleh undang-undang. Dilarang memperbanyak karya tulis ini dalam bentuk apapun tanpa izin penerbit 


\section{KATA PENGANTAR}

Assalamu'alaikum Warahmatullahi Wabarakatuh,

Alhamdullilah Segala puji dan syukur penulis panjatkan kehadirat Allah SWT yang telah melimpahkan rahmat dan karunia-Nya kepada kita semua. Sholawat serta salam tak lupa pula kami haturkan kepada junjungan kita Nabi Muhammad SAW atas selesainya buku ini.

Buku ini disusun agar dapat membantu para mahasiswa dalam mempelajari dasar dasar manajemen serta mempermudah mempelajari materi manajemen terutama bagi kaum awam yang belum mengenal dasar dasar manajemen itu sendiri, Buku ini terdiri atas dua puluh empat bab, cakupan materi yang dibahas meliputi teori dasar dasar Manajemen, Harapan penulis, agar buku ini dapat menjadi bahan pendamping bagi mahasiswa yang mengambil Jurusan Manajemen.

Penulis pun menyadari jika didalam penyusunan buku ini jauh dari sempurna, namun penulis meyakini sepenuhnya bahwa sekecil apapun buku ini tetap akan memberikan sebuah manfaat bagi pembaca maka sangat berterima kasih bila ada kritik dan saran untuk perbaikan pada edisi berikutnya.

Semoga Buku yang kami buat dapat bermanfaat untuk para pembaca semua.Sekian dan terima kasih.

Wassalamualaikum Warahmatullahi Wabarakatuh

Jakarta 08 Desember 2020

Penulis 


\section{DAFTAR ISI}

KATA PENGANTAR ................................................................ ii

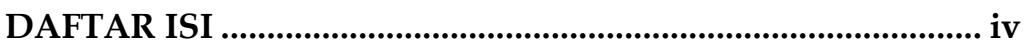

DAFTAR GAMBAR............................................................. v

BAB 1 PENDEKATAN-PENDEKATAN ILMU

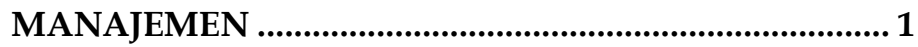

BAB 2 FUNGSI-FUNGSI MANAJEMEN .................................. 4

BAB 3 MANAJER SEBAGAI PEMBUAT KEPUTUSAN............. 10

BAB 4 MERENCANAKAN SASARAN DAN TUJUAN.............. 16

BAB 5 KERJA PERENCANAAN ............................................ 23

BAB 6LANDASAN PEMIKIRAN, SIASAT, DAN

KEBIJAKSANAAN ........................................................... 28

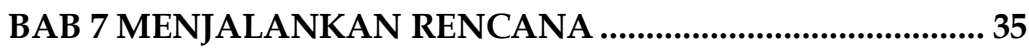

BAB 8 KONSEP-KONSEP ORGANISASI ................................... 40

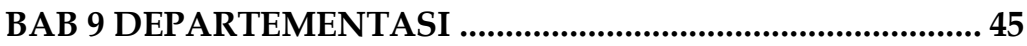

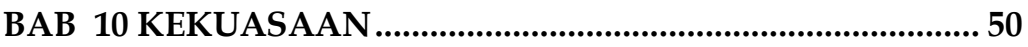

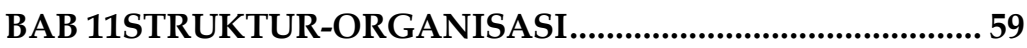

BAB 12 ORGANISASI: KELOMPOK-KELOMPOK KERJA

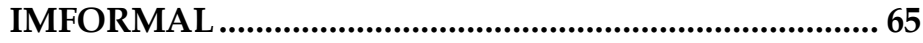

BAB 13 DINAMIKA ORGANISASI........................................ 73

BAB 14 PENYUSUNAN STAF ORGANISASI ............................ 84

BAB 15 MOTIVASI DAN MANAJER-MANAJER

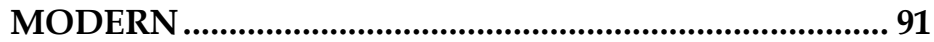

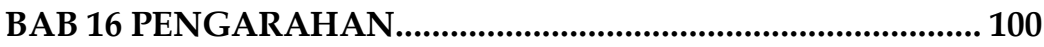

BAB 17 KEPEMIMPINAN DALAM MANAJEMEN.................... 108

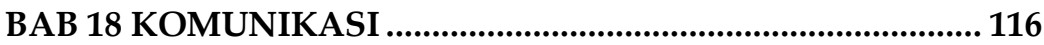

BAB 19 PENILAIAN DAN PENGEMBANGAN

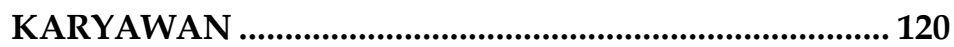

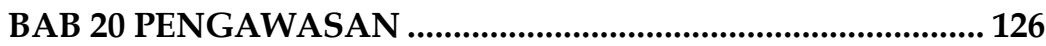

BAB 21 BIDANG-BIDANG KUNCI PENGAWASAN ............... 131

BAB 22 PENGAWASAN MENYELURUH ....................................139

BAB 23 MANAJEMEN INTERNASIONAL ................................. 146

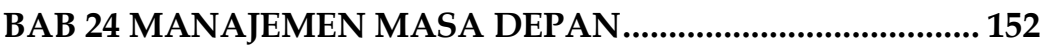

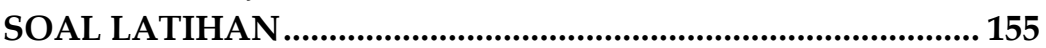

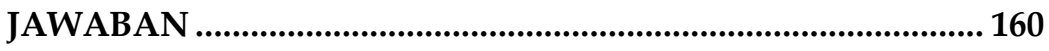

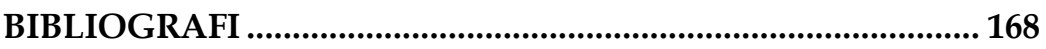


TETANG PENULIS 


\section{DAFTAR GAMBAR}

Gambar 2.2 Bagaimana Cara Para Manajer ……........................ 8

Gambar 5.1 Kekuatan Perencanaan Formal vs Informal ............25

Gambar 6.1 Ramalan Perluasan Penjualan................................29

Gambar 8.1 Komponen-komponen Nyata...................................43

Gambar 8.2 Contoh Struktur Organisasi .....................................4

Gambar 10.1 Sentralisasi Keputusan.............................................5

Gambar 10.2 Pengaturan yang Didesentralisasikan ..................56

Gambar 10.3 Perbandingan Otoritas Garis dengan Kekuasaan

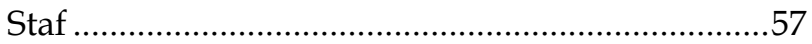

Gambar 11.1 Struktur organisasi garis staf

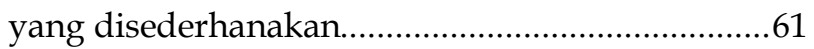

Gambar 11.2 Ilustrasi Matriks Organisasi ..................................62

Gambar 12.1 Keuntungan-Keuntungan Potensial dari Kelompok Kerja Informasi......................................................71

Gambar 12.2Faktor-faktor Kunci Dalam Berurusan dengan

Kelompok-kelompok Kerja Informasi ......................71

Gambar 13.1 Perkembangan Departemen..................................77

Gambar 13.2 Divisionalisasi Menurut Hasil Produksi ................78

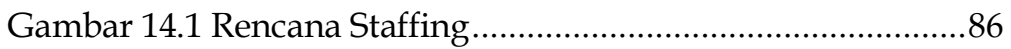

Gambar 20.1 Alat Pengatur Suhu Rumah Tangga sebagai Contoh dari Proses Pengawasan........................................127

Gambar 21.1 Peta Pengawasan Kualitas......................................133

Gambar 21.2 Biaya Keseluruhan ................................................136

Gambar 22.1 Contoh Laporan Sederhana....................................141

Gambar 22.2 Perhitungan-Perhitungan untuk Pengembalian

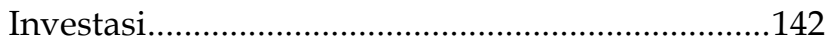

Gambar 22.3 Peta Break Even......................................................143 


\section{DASAR-DASAR MANAJEMEN Teori, Fungsi dan Konsep}





\section{BAB 1 \\ PENDEKATAN-PENDEKATAN ILMU \\ MANAJEMEN}

\section{A. Kerangka 1.1}

Manajemen adalah suatu proses atau kerangka kerja, yang melibatkan bimbingan atau pengarahan suatu kelompok orang-orang kea rah tujuan organisasional atau maksud-maksud yang nyata. Manajemen adalah suatu kegiatan, pelaksanaannya disebut manajer atau pengelola.

Pada hakikatnya, tugas seorang manajer adalah menggunakan usaha para bawahan secara berdaya guna. Berdasarkan definisi di atas maka biasanya manajemen dihubungkan dengan suatu kelompok. Usaha bersama-sama (cooperative endeavour) adalah ungkapan zaman sekarang.

Manajemen mempunyai tujuan mencapai hasil-hasil tertentu, yang biasanya diungkapkan dengan istilah objectives. Manajemen dapat digambarkan sebagai hal yang tidak nyata, tetapi hanya terbukti oleh hasil-hasil yang ditimbulkannya (output) atau hasil kerja yang memadai, kepuasan manusiawi, dan hasil-hasil produksi, serta jasa yang lebih baik.

\section{B. Kerangka 2.1}

Menjelang pertengahan pertama abad ke-19, manajemen sudah membuat kemajuan setara dengan peningkatan alat-alat produksi. Sepanjang abad ke-19 dan 20, banyak peneliti, industrialis, dan pegawai pemerintah yang tertarik pada manajemen. Kira-kira tahun 1939, prinsip bahwa manusia merupakan pertimbangan terpenting dalam manajemen mendapat angin dan menyebabkan banyak orang berpaling kepada penelitian perilaku manusia.

Beberapa dasawarsa kemudian tersedialah computer, yang membawa penekanan lebih besar pada metode-metode analis kuantitatif dalam manajemen. Penggunaan matematika dan statistik merupakan pendekatan yang baru terhadap 
manajemen. Manajemen adalah salah satu pokok pembahasan yang universal, dan konsep itu menarik peneliti-peneliti dan para praktisi dari bidang-bidang yang sangat beraneka ragam termasuk di dalamnya ilmu-ilmu ekonomi, psikologi, sosiologi, ilmu politik, dan matematika. Terdapat empat macam pendekatan utama, yaitu, sebagai berikut.

1. Proses Pendekatan Operasional

Penganut-penganut pendekatan ini memandang manajemen sebagai suatu proses universal, terlepas dari jenis atau tingkat organisasi. Akan tetapi, mereka juga mengakui bahwa lingkungan-lingkungan internal maupun eksternal, di mana proses manajemen itu digunakan, sangat berbeda-beda di antara organisasi-organisasi dan pada berbagai tingkat.

2. Pendekatan Perilaku Manusia

Inti pendekatan ini adalah perilaku manusia khususnya psikologi dan antropologi. Sebagian orang memandang manajer itu sebagai pemimpin dan memperlakukan semua kegiatan-kegiatan orang yang dipimpinnya sebagai keadaan-keadaan manajerial.

3. Pendekatan Sistem Sosial

Dengan kata lain sebagai suatu sistem interrelasi budaya. Berorientasi secara sosiologis, berurusan dengan berbagai kelompok sosial dan hubungan-hubungan budayanya, serta berusaha menyatukan kelompokkelompok ini ke dalam suatu sistem sosial. Memperhitungkan pertimbangan-pertimbangan etika, pengaruh masyarakat, serikat-serikat pekerja, dan pemerintahan. Pengikut-pengikut pendekatan sistem-sistem ini bertujuan mengembangkan suatu kerangka sistematis untuk menguaraikan hubungan-hubungan antar aktivitas.

4. Pendekatan Kuantitatif

Penggunaan model-model matematika dan proses, serta hubungan-hubungan dan data yang dapat diukur. Pendekatan ini memakai si pemakai untuk mendefinisikan dengan tepat segala tujuan persoalan dan hubungan dengan 
cara yang dapat diukur. Dengan demikian, pendekatan ini paling efektif jika digunakan pada tanda-tanda fisik seperti inventaris, jarak-jarak angkutan, dan campuran-campuran hasil. 


\section{BAB 2 \\ FUNGSI-FUNGSI MANAJEMEN}

\section{A. Kerangka 1.2}

Proses atau pendekatan operasional mempersamakan manajemen, dengan apa yang dibuat seorang manajer untuk memenuhi persyaratan sebagai seorang manajer. Sebaiknya, apa yang dibuat oleh sang manajer adalah berbeda. Ia adalah suatu aktivis yang dibentuk oleh beberapa fungsi pokok.

Berikut ini adalah pengertian manajemen yang dikemukakan oleh para ahli.

1. Ricky W. Griffin dalam buku Management, mendefinisikan bahwa manajemen sebagai sebuha proses perencanaan, pengorganisasian, pengirdinasian dan pengontrolan sumber daya untuk mencapai sasaran (goals) secara efektif dan efisien. Efektif berarti berarti tujuan dapat dicapai sesuai dengan perencanaan, sementara efisien berarti tugas yanga ada dilaksanakan secara benar, terorganisir dan sesuai dengan jadwal.

2. George R. Terry, Ph.D dalam bukunya Principles of Management menyatakan bahwa manejemn adalah pencapaian suatu tujuan yang telah ditentukan sebelumnya melalui usaha-usaha orang-orang lai

3. Harold Koontz dan Cyril O'Donnel dalam bukunya Principles of Management menyatakan bahwa manajemen adalah fungsi mencapai suatu melalui orang-orang.

4. E. F. L. Brech dalam bukunya Management menyatakan bahwa manajemen adalah suatu proses dan lebih khusus adalah suatu proses social. Manajemen adalah sesuatu yang dilakukan ornag dalam hubungannya dengan orang-orang lain.

5. Milon Brown dalam bukunya Effective Work Management mengungkapkan bahwa manajemen adalah penggunaan orang-orang, uang, perlengkapan, bahan-bahan, dan 
metode-metode yang efektif untuk mencapai suatu tujuan tertentu.

\section{Lima Fungsi Utama}

Penting untuk diingat bahwa manajemen adalah bentuk kerja. Manajer dalam melakukan pekerjaannya harus melaksanakan kegiatan-kegiatan tertentu yang dinamakan fungsi-fungsi manajemen, yang terdiri dari berikut ini.

1. Planning- menentukan tujuan-tujuan yang hendak dicapai selama suatu masa yang akan datang, dan apa yang harus diperbuat agar dapat mencapai tujuan-tujuan itu.

2. Organizing- mengelempokkan, menentukan berbagai kegiatan penting, dan memberikan kekuasaan untuk melaksanakan kegiatan-kegiatan itu.

3. Staffing- menentukan keperluan-keperluan sumber daya manusia, pengerahan, penyaringan, latihan, dan pengembangan tenaga kerja.

4. Motivating- mengarahkan atau menyalurkan perilaku manusia ke arah tujuan-tujuan.

5. Controlling- mengukur pelaksanaan dengan tujuan-tujuan, menentukan berbagai sebab penyimpangan-penyimpangan dan mengambil tindakan-tindakan korektif yang diperlukan.

Gambar 2.1 selanjutnya memerinci jenis-jenis khusus kegiatan-kegiatan yang terlibat dalam masing-masing fungsi manajemen. Setiap tingkat manajemen tidak menggunakan kombinasi yang sama dari fungsi-fungsi ini.

Seorang manajer tingkat pertama (pengawas) mungkin menggunakan kombinasi 10 persen perencanaan, 10 persen pengaturan, 10 persen kepegawaian, 40 persen pemberian motivasi, dan 30 persen pengawasan. Seorang manajer tingkat puncak seperti seorang presiden sebuah korporasi, mungkin menggunakan kombinasi 30 persen perencanaan, 20 persen pengorganisasian, 20 persen penggunaan pegawai, 15 persen pemberian motivasi, dan 15 persen pengawasan. Seorang 
manajer yang melewatkan hamper semua waktu untuk menjalankan satu fungsi saja dengan mengabaikan satu atau lebih fungsi-fungsi lainnya, seharusnya menganalisa dengan cermat pelaksanaan pekerjaannya. Gambar 2.2 memberikan beberapa petunjuk umum mengenai cara bagaimana para manajer pada berbagai tingkat, cenderung menentukan pembagian waktu mereka.

Fungsi-Fungsi Manajemen

1. Perencanaan:

a. Self-audit- menentukan keadaan-keadaan organisasi sekarang.

b. Survei lingkungan.

c. Menentukan tujuan (objectives).

d. Forecast, ramalan mengenai keadaan-keadaan yang akan dating.

e. Melakukan tindakan-tindakan dan sumber pengarahan.

f. Evaluate, pertimbangan tindakan-tindakan yang diusulkan.

g. Ubah dan sesuaikan (revise and adjust) rencana-rencana sehubungan dengan hasil-hasil pengawasan dan keadaan-keadaan yang berubah-ubah.

h. Communicate, berhubungan terus selama proses perencanaan.

2. Pengorganisasian:

a. Identity, tetapkan dengan teliti dan tentukan pekerjaan yang akan dilaksanakan.

b. Break work down, bagi-bagi pekerjaan menjadi tugas-tugas setiap orang.

c. Tugas-tugas kelompok menjadi posisi-posisi.

d. Tentukan persyaratan-persyaratan setiap posisi.

e. Kelompok-kelompok posisi menjadi satuan-satuan yang dapat dipimpin dan saling berhubungan dengan baik.

f. Bagi-bagikan pekerjaan, pertanggungjawaban dan luas kekuasaan yang akan dilaksanakan. 
g. Ubah dan sesuaikan organisasi sehubungan dengan hasil-hasil pengawasan dan berbagai kondisi yang berubah-ubah.

h. Berhubungan selalu selama proses pengorganisasian.

3. Kepegawaian:

a. Tentukan keperluan-keperluan sumber daya manusia.

b. Kerahkanlah pegawai-pegawai sedapat mungkin.

c. Saringlah sumber daya manusia.

d. Latih dan kembangkan sumber-sumber daya manusia.

e. Ubah dan sesuaikan kuantitas dan kualitas sumbersumber daya manusia sehubungan dengan hasil-hasil pengawasan dan perubahan-perubahan kondisi.

f. Berhubungan setelah dan selama proses pengisian pegawai

4. Pemotivasian:

a. Berhubungan dengan staf dan jelaskan tujuan-tujuan kepada bawahan.

b. Bagi-bagikan ukuran-ukuran pelaksanaan (performances standards).

c. Latih dan bimbing bawahan untuk memenuhi ukuranukuran pelaksanaan itu.

d. Beri bawahan upah berdasarkan pelaksanaan.

e. Puji dan tegur dengan jujur.

f. Adakan lingkungan yang memberikan dorongan dengan meneruskan keadaan yang berubah-ubah, serta tuntutantuntutannya.

g. Ubah dan sesuaikan cara-cara dalam memotivasi sehubungan dengan hasil pengawasan dan kondisi yang berubah.

h. Berhubungan selalu selama proses pemotivasian.

5. Pengawasan:

1. Tetapkan ukuran-ukuran. 
2. Monitor hasil-hasil dan bandingkan dengan ukuranukuran.

3. Perbaiki penyimpangan-penyimpangan.

4. Ubah dan sesuaikan cara-cara pengawasan sehubungan dengan hasil-hasil pengawasan dan perubahan kondisikondisi.

5. Berhubungan selalu selama proses pengawasan.

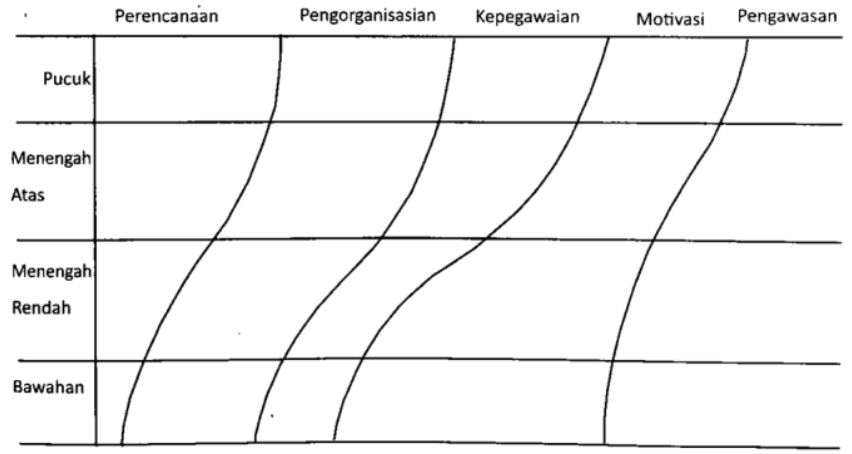

Gambar 2.2 Bagaimana cara para manajer di tingkat yang berbeda dalam membagi-bagikan waktunya

\section{Memberi Nama Bagi Fungsi-Fungsi Itu}

Tidak semua penulis sepakat mengenai nama apa yang harus diberikan kepada fungsi manajemen itu. Ada kesepakatan umum bahwa perencanaan, pengorganisasian, dan pengawasan harus disebutkan sebagai fungsi-fungsi manajemen. Sebagian penulis memasukkan fungsi kepegawaian sebagai suatu bagian dalam fungsi pengorganisasian. Beberapa penulis lain menggunakan motivating, sebagian lagi directing, sedang yang lain menggunakan leading, influencing, atau actuating (memimpin, memengaruhi, atau menjalankan). Istilah motivating akan digunakan dalam buku ini.

Haruslah ditekankan bahwa fungsi-fungsi dasar dari manajemen adalah saling berkaitan. Perencanaan umpamanya memengaruhi pengorganisasian, dan pengorganisasian 
memengaruhi pengawasan. Fungis-fungsi saling menjalin tanpa terpisahkan, dan biasanya mereka tidak dijalankan dalam suatu urutan tertentu, tetapi tampaknya menurut yang dikehendaki sesuai keperluan masing-masing. Untuk melancarkan suatu organisasi baru, biasanya dimulai dengan perencanaan, diikuti oleh fungsi=fungsi lain. Bagi suatu organisasi yang sudah mapan, pengawasan pada waktu tertentu mungkin diikuti dengan perencanaan, dan sebaliknya, diikuti dengan pemotivasian. 


\section{BAB 3 \\ MANAJER SEBAGAI PEMBUAT \\ KEPUTUSAN}

\section{A. Kerangka 1.3}

Sebuah ciri umum seorang manajer adalah bahwa ia merupakan seorang pembuat keputusan. Seorang manajer harus memutuskan tujuan-tujuan yang hendak dikerjakan. Membuat keputusan adalah memilih suatu alternatif dari dua pilihan atau lebih, untuk menentukan suatu pendapat atau perjalanan suatu tindakan. Dalam pengambilan keputusan, seorang manajer berurusan dengan nilai-nilai yang akan datang, yang sampai tingkat tertentu masih belum diketahui. Selanjutnya, penyaringan suatu pilihan selalu didasarkan atas beberapa kriteria, seperti menghemat ongkos, menghemat waktu, atau meningkatkan kualitas para manajer. Agar pembuatan keputusan dapat dilakukan, haruslah ada dua pilihan atau lebih. Dalam banyak hal, hanya ada dua pilihan saja, misalnya jenis tinggi atau terendah; atau jenis ya atau tidak.

Beberapa tokoh juga menyampaikan pendapatnya, Berikut pengertian keputusan dan pengambil keputusan menurut para tokoh

Ralph C. Davis (Hasan, 2004) memberikan definisi atau atau pengertian keputusan sebagai hasil pemecahan masalah yang dihadapinya dengan tegas. Suatu keputusan merupakan jawaban yang pasti terhadap suatu pertanyaan. Keputusan harus dapat menjawab pertanyaan tentang apa yang dibicarakan dalam hubungannya dengan perencanaan. Keputusan dapat pula berupa tindakan terhadap pelaksanaan yang sangat menyimpang dari rencana semula.

Mary Follet memberikan definisi atau pengertian keputusan sebagai suatu atau sebagai hokum situasi. Apabila semua fakta dari situasi itu dapat diperolehnya dan semuayang terlibat, baik pengawas maupun pelaksana mau mentaati 
hukumannya atau ketentuannya, maka tidak sama dengan mentaati perintah. Wewenang tinggal dijalankan, tetapi itu merupakan wewenang dari hukum situasi.

G. R. Terry Pengambilan keputusan dapat didefenisikan sebagai pemilihan alternatif kelakuan tertentu dari dua atau lebih alternatif yang ada.

Harold Koontz dan Cyril ODonnel Pengambilan keputusan adalah pemilihan diantara alternatif-alternatif mengenai sesuatu cara bertindakadalah inti dari perencanaan. Suatu rencana dapat dikatakan tidak ada, jika tidak ada keputusan suatu sumber yang dapat dipercaya, petunjuk atau reputasi yang telah dibuat.

Theo Haiman menilai bahwa inti dari semua perencanaan adalah pengambilan keputusan, suatu pemilihan cara bertindak. Dalam hubungan ini kita melihat keputusan sebagai suatu cara bertindak yang dipilih oleh manajer sebagai suatu yang paling efektif, berarti penempatan untuk mencapai sasaran dan pemecahan masalah.

Drs. H. Malayu S.P Hasibuan pengambilan keputusan adalah suatu proses penentuan keputusan yang terbaik dari jumlah alternative untuk melakukan aktifitas- aktifitas pada masa yang akan datang.

Chester I. Barnard mendefenisikan Keputusan sebagai perilaku organisasi, berintisari perilaku perorangan dan dalam gambaran proses keputusan ini secara relative dan dapat dikatakan bahwa pengertian tingkah laku organisasi lebih penting dari pada kepentingan perorangan.

\section{Mengevaluasi Faktor-Faktor Keputusan}

Dalam usaha-usaha ini ditinjau faktor-faktor dan tindakan nyata dan tindakan tersembunyi. Yang pertama mencakup keuntungan-keuntungan, dollar, jam kerja, jam produksi, dan data kuantitatif lainnya yang sudah ditetapkan. Untuk memberikan suatu penggambaran maksimasi keuntungan biasanya, buat sebagian tergantung dari perbandingan berbagai faktor fisik. Dalam perencanaan 